\title{
GAYA BERCERITA DALAM NOVEL REMBULAN TENGGELAM DI WAJAHMU KARYA TERE LIYE
}

\author{
'Elza Apriani; ${ }^{2}$ Amrizal; ${ }^{3}$ Amril Canrhas
}

\section{${ }^{1,2,3}$ Program Studi Pendidikan Bahasa Indonesia FKIP Universitas Bengkulu}

\section{Abstrak}

\section{Korespondensi: elzaapriani23@gmail.com}

Tujuan penelitian ini yaitu untuk mengetahui dan mendeskripsikan gaya bercerita Tere Liye dalam novel Rembulan Tenggelam Di Wajahmu menggunakan metode deskriptif yang digunakan untuk mendeskripsikan atau menggambarkan data-data yang berkaitan dengan gaya bercerita. Pendekatan dalam penelitian ini yaitu pendekatan stilistika yang digunakan untuk mengkaji gaya bercerita dalam novel Rembulan Tenggelam di Wajahmu. Langkah-langkah dalam penelitian ini yaitu; (1) membaca dan memahami secara seksama novel Rembulan Tenggelam di Wajahmu karya Tere Liye; (2) membuat sinopsis novel Rembulan Tenggelam di Wajahmu karya Tere Liye; (3) mengumpulkan data-data yang menunjukkan gaya bercerita pengarang dalam novel Rembulan Tenggelam di Wajahmu karya Tere Liye; (4)mengelompokkan data-data yang menunjukkan gaya bercerita pengarang; (5) mengidentifikasi data yang diperoleh berdasarkan jenis-jenis gaya bercerita pengarang; (6) menganalisis gaya bercerita pengarang berupa runtutan kronologis peristiwa pada setiap bagian; (7) menarik kesimpulan. Gaya bahasa yang ditemukan oleh penulis dalam penelitian ini yaitu gaya bahasa personifikasi, asosiasi atau perumpamaan, sarkasme, hiperbola, dan simile. Tidak hanya itu, penelitian ini juga menganalisis sampai pada perwatakan tokoh, karena gaya bahasa tertentu juga menjadi ciri tokoh juga. Teknik pelukisan tokoh tersebut adalah teknik dramatik yang meliputi teknik cakapan, tingkah laku, pikiran dan perasaan, arus kesadaran, reaksi tokoh, reaksi tokoh lain, pelukisan latar dan pelukisan fisik. Dalam novel Rembulan Tenggelam Di Wajahmu karya Tere Liye, penulis juga menemukan beberapa latar atau setting yang terdapat di dalamnya, yaitu; (1) latar tempat di Rumah Singgah, Toilet Terminal, Gerbong Makan, Rumah Fitri, Pinggir Pantai, Bandara Kota, Rumah Sakit, (2) latar waktu yaitu pada malam hari, dan sore hari, (3) latar suasana yaitu suasana sepi, suasana gelap gulita, suasana ramai, suasana ketakutan, suasana gembira.

Kata Kunci: gaya bercerita, novel, Rembulan Tenggelam di Wajahmu, stilistika

\footnotetext{
Abstract

The purpose of the research is to find out in describe the style tells the story of Tere Liye in the novel Rembulan Tenggelam di Wajahmu. Using descriptive method used to describe of describe data related to the style of storytelling. Approach in this study the stylistic approach is used to study the storytelling style in the novel Rembulan Tenggelam di Wajahmu. The steps in this study namely; (1) carefully read and understand the novel Rembulan Tenggelam di Wajahmu by Tere Liye; (2) make a synopsis of the novel Rembulan Tenggelam di Wajahmu by Tere Liye; (3) collecting data which shows the author's storytelling style in the novel Rembulan
} 


\section{Elza Apriani; Amrizal; Amril Canrhas}

Tenggelam di Wajahmu by Tere Liye; (4) grouping data that shows author's story style; (5) identify the data obtained based on types of author stories; (6) analyzing the author's stories; (7) analyzing the author's. Storytelling style in the from chronological sequence of events in each section draw conclusions. The style of language found by the authors in this study is the style of language personification, association or parable, sarcasm, hyperbole, and simile. Not only that, this study also characterizes the character as well. The character's drawing techniques is a dramatic technique that includes techniques behavior, mind and feelings, streams of awareness, reactions of characters, reactions of other characters, setting and background physical painting. In the novel Novel Rembulan Tenggelam Di Wajahmu by Tere Liye, the author also found several settings or settings contained in it that is, (1) background of the shelter house, Terminal, Toilet, Dining car Fitri home, Coastal, Airport City, Hospital, (2) time setting leat nigh, and in the afternoon, (3) the atmosphere is quiet, dark pitch black, the atmosphere is crowded, the atmosphere of fear, an atmosphere of Jo.

Keywords: storytelling style, novels, moon sinks in your face, stylistic

\section{PENDAHULUAN}

Sesuatu yang bernilai adalah sesuatu yang berguna dan bermanfaat. Salah satu objek yang mempunyai daya tarik untuk diteliti dan dikaji yaitu karya sastra. Menurut Ratna (2008: 159) karya sastra adalah sistem model pertama sekaligus kontekstual. Benar, karya sastra dihasilkan oleh pengarang sebagai subjek individual, tetapi perlu disadari bahwa pengarang hidup dalam masyarakat sehingga keberadaan amanat, dan unsur-unsur lainnya dalam karya sastra ditentukan oleh masyarakat. Karya sastra lahir disebabkan oleh beberapa faktor, salah satunya adalah karena latar belakang sosial pengarang dan hasrat untuk mengungkapkan pendapat mengenai kehidupan dengan berbagai polemik atau persoalan di dalamnya. Menurut Semi (2012:1) bahwa sastra lahir disebabkan oleh dorongan dasar manusia untuk mengungkapkan dirinya, menaruh minat terhadap masalah manusia dan kemanusiaan, dan menaruh minat terhadap realitas yang berlangsung sepanjang hari dan sepanjang zaman.

Zaman sekarang, salah satu jenis karya sastra yang banyak digemari oleh anak muda maupun orang dewasa adalah novel. Novel bersifat meluas dan cenderung menitikberatkan munculnya kompleksitas. Hal ini diperkuat oleh A. Sayuti (2000: 11) yang mengenai tempat (ruang) tertentu. Novel adalah karangan prosa yang panjang dan mengandung rangkaian cerita kehidupan seseorang dengan orang-orang di sekelilingnya yang penceritaannya dengan cara menonjolkan watak dan sifat setiap pelaku atau tokoh. Novel biasanya menceritakan tokoh dan kehidupan sehari-hari yang sarat akan nilai-nilai kehidupan. Novel biasanya menceritakan tokoh dan kehidupan sehari-hari yang sarat akan nilai-nilai kehidupan. Pengungkapan masalah kehidupan manusia merupakan hasil perpaduan daya imajinasi, ekspresi dan daya kreasi dengan pengalaman dan mata batin pengarang atau sastrawan.

Hasil kreatif seorang pengarang terhadap novel, selain membutuhkan tokoh, cerita, plot dan latar juga menggunakan unsur gaya bercerita kepengarangan yang khas. Hal ini sangat penting, karena karya itu akan terasa hidup, berjiwa dan menyenangkan apabila seorang pengarang mampu menggunakan gaya berceritanya dengan baik.

Di Indonesia banyak sekali novelis yang sudah banyak menghasilkan karyakaryanya dengan menggunakan ciri khas atau gaya bercerita masing-masing. Salah satu 
novelis yang terkenal di Indonesia yaitu Tere Liye, hal ini terbukti dengan banyaknya karya-karya yang sudah berhasil ia terbitkan salah satunya novel Rembulan Tenggelam di Wajahmu. Novel Rembulan Tenggelam di Wajahmu merupakan salah satu novel terlaris dan best seller karya Tere Liye, hal ini terbukti dari sejak awal terbit hingga tahun 2015 novel ini sudah dicetak ulang sebanyak dua puluh satu kali cetakan. Selain itu, novel ini juga mempunyai sisi menarik dari segi jalan cerita walaupun pada novel ini mengharuskan pembaca untuk membaca keseluruhan novel karena setiap bab mempunyai kejutan. Novel Rembulan Tenggelam di Wajahmu lebih dominan membahas tentang konflik kehidupan manusia, dan dalam novel ini Tere Liye mengantarkan pembaca untuk dapat melihat perjalanan hidup manusia yang penuh dengan lika-liku hingga membuat tokoh utama dalam novel ini menjadi tersadar akan perbuatan yang dilakukan selama hidupnya.

Bahasa dalam sastra dimanfaatkan dan dipilih oleh pengarang untuk menciptakan suatu pesan keindahan dan memiliki makna dalam karyanya, karena dengan menggunakan bahasa pengarang dapat berkomunikasi dengan pembaca. Pemilihan bahasa yang indah dalam karya sastra adalah gaya bahasa, gaya bahasa sendiri merupakan cara mengungkapkan pikiran melalui bahasa secara khas yang memperlihatkan jiwa dan kepribadian penulis atau pemakai bahasa (Keraf, 2009: 113).

Seorang sastrawan menghasilkan karya-karyanya dikarenakan adanya tuntutan dari pembaca yang membuat ia harus menghasilkan karya lebih banyak lagi. Hal ini disebabkan oleh gaya bercerita pengarang yang membuat pembaca menjadi semakin tertarik, selalu mengenang, dan penasaran untuk terus membaca karya-karya yang dihasilkan oleh pengarang tersebut. Tidak jarang, ada juga pembaca setelah membaca karya-karya pengarang tertentu ia merasa sangat bosan. Hal ini juga disebabkan oleh gaya bercerita pengarang yang tidak sama dengan pola pikirnya.

Tere Liye merupakan penulis novel yang memiliki kekhasan dalam menggunakan bahasa. Kekhasan lain dalam novel Rembulan Tenggelam di Wajahmu terletak pada jalan cerita yang sederhana, dengan penempatan bahasa yang tepat. Selain itu, Tere Liye merupakan seorang seniman kata yang kuat dengan menggunakan gaya bahasa yang sederhana sehingga sangat memungkinkan pembaca akan terpengaruh dan dapat memahami makna yang terdapat dalam novel yang dihasilkannya.

Salah satu cara untuk membedah gaya bercerita pengarang adalah dengan meneliti kekhasan dan keunikan penggunaan bahasa pengarang dalam karyanya. Untuk mengkaji penggunaan bahasa dalam karya sastra dapat dilakukan dengan pendekatan stilistika. Stilistika ini merupakan ilmu yang berbau linguistik dalam mengkaji karya sastra. Kajian stilistika ini bertujuan untuk meneliti kekhasan dan aspek khusus penggunaan bahasa dalam karya sastra.

Berdasarkan latar belakang yang telah diuraikan maka peneliti bermaksud untuk melakukan penelitian berjudul "Gaya Bercerita Dalam Novel Rembulan Tenggelam di Wajahmu Karya Tere Lie"..

\section{METODE}

Pada dasarnya penelitian ini bersifat kualitatif. Sedangkan pada penyajian hasil penulisan menggunakan metode deskriptif. Dalam penelitian ini menggunakan pendekatan stilistika, yang diarahkan pada pemakaian kata dan kalimat serta paragraf yang menjadi gaya bercerita dari seorang pengarang dalam suatu karya sastra. Data yang digunakan dalam penelitian ini adalah kutipan-kutipan kalimat yang menunjukkan gaya bercerita 
pengarang. Sedangkan sumber data dalam penelitian ini adalah novel Rembulan Tenggelam di Wajahmu karya Tere Liye, cetakan 3 tahun 2009 dengan jumlah halaman 426, dan terbitan Republika. Teknik pengumpulan data yang digunakan dalam penelitian ini adalah teknik studi pustaka. Teknik analisis data yang digunakan analisis deskriptif kualitatif ini adalah membaca dan memahami novel, membuat sinopsis, mengelompokkan, mengidentifikasi, mengklasifikasi, menganalisis dan mengkaji, dan menarik kesimpulan.

\section{HASIL DAN PEMBAHASAN}

\section{Hasil}

A. Gaya Bercerita Pengarang

Pada novel Rembulan Tenggelam di Wajahmu, Tere Liye menggunakan teknik pelukisan tokoh dalam cerita menggunakan teknik dramatik yang meliputi teknik cakapan, pikiran dan perasaan, arus kesadaran, reaksi tokoh, reaksi tokoh lain, pelukisan fisik, dan pelukisan latar.

B. Gaya Bahasa

Gaya bahasa yang peneliti temukan dalam novel Rembulan Tenggelam di Wajahmu karya Tere Liye yaitu, personifikasi, asosiasi atau perumpamaan, sarkasme, hiperbola, dan simile.

C. Latar atau Setting

Pada novel Rembulan Tenggelam di Wajahmu karya Tere Liye ini, penulis menemukan latar atau setting yaitu (1) latar tempat di Rumah Singgah, Toilet, Terminal, Gerbong Makan, Rumah Fitri, Pinggir Pantai, Bandara Kota, dan Rumah Sakit, (2) latar waktu yaitu pada malam hari dan sore hari, (3)latar suasana yaitu suasana sepi, suasana gelap gulita, suasana ramai, suasana ketakutan, dan suasana gembira.

\section{Pembahasan}

A. Gaya Bercerita Pengarang

Setiap pengarang tentu memiliki gaya penceritaan yang berbeda-beda, entah dalam konteks maupun teknik yang digunakannya. Seperti halnya kajian stilistika yang kerap menyinggung permasalahan corak individual yang khas dari penulis karena penulis yang mapan dianggap tentu mempunyai gaya tersendiri menurut Semi dalam Endraswara (2003: 74-75). Dalam novel Rembulan Tenggelam Di Wajahmu kepengarangan yang digunakan Tere Liye akhirnya membentuk gaya bercerita yang khas bagi kepengarangannya.

Bagian ini akan penulis paparkan mengenai gaya bercerita Tere Liye dalam novel Rembulan Tenggelam di Wajahmu. Teknik pelukisan tokoh tersebut adalah teknik dramatik yang meliputi teknik cakapan, tingkah laku, pikiran dan perasaan, arus kesadaran, reaksi tokoh, reaksi tokoh lain, pelukisan latar dan pelukisan fisik (Nurgiyantoro, 2013: 283-296).

Berikut penulis paparkan teknik cakapan yang terdapat dalam novel Rembulan Tenggelam Di Wajahmu disertai kutipannya:

"Mengaku atau kupukul?"

"Aku tidak tahu."

“Mengaku atau kupukul!” Rotan itu teracung kedepan. 
“AKU TIDAK MELAKUKANNYA!”. Rehan melawan, berteriak bahkan. Percuma, bukan? Mengaku pun dia tetap dipukul. Tidak ada bedanya.

“Mengaku atau k-u-p-u-k-u-l!” Pecut rotan itu semakin dekat." ( Liye, 2009: 11)

Dari kutipan di atas terlihat bahwa Tere Liye melukiskan tokoh Rehan Raujana alias Ray melalui teknik cakapan tersebut dengan menyiratkan sifat Ray yang keras dan teguh pendirian. Hal ini terlihat saat cakapan berlangsung dimana Penjaga Panti yang terus berusaha mendesak Ray agar ia mengakui kesalahannya, namun pada cakapan tersebut Ray tetap tidak mengakuinya. Pada cakapan di atas itulah tersirat bahwa sifat Ray itu yaitu seseorang yang keras dan teguh pendirian. Teknik tingkah laku adalah teknik yang bersifat nonverbal atau lebih mengarah ke fisik.

"Apa yang orang-orang bilang? Penjaga Panti itu sejak lama menyimpan mimpi secara berlebihan. Mimpi yang membuatnya mati-matian mengumpulkan uang untuk dirinya sendiri. Penjaga Panti itu mau naik haji. Peduli amat dari mana uangnya berasal." (Liye, 2009: 15)

Kutipan di atas menggambarkan bagaimana Tere Liye melukiskan tingkah laku Penjaga Panti yang mempunyai cita-cita yang mulia untuk menunaikan salah satu rukun Islam yaitu naik haji. Namun dari kutipan tersebut, juga tergambar bagaimana watak Penjaga Panti yang sebenarnya. Penjaga Panti adalah seseorang yang menghalalkan segala cara untuk dapat mewujudkan cita-citanya.

Di dalam novel Rembulan Tenggelam di Wajahmu karya Tere Liye penulis menemukan gaya bercerita Tere liye yang menggunakan teknik pikiran dan perasaan. Teknik pikiran dan perasaan adalah teknik yang melukiskan bagaimana keadaan, jalan pikiran dan perasaan yang terlintas dalam pikiran tokoh.

"Setelah sekian lama menanti jawaban, Rinai perlahan menunduk. Pegal, kepalanya lelah mendongak. Kalau anak-anak lain punya Ayah, kenapa ia tidak? Kalau anak-anak lain punya Bunda, kenapa ia tidak? Ia sungguh tidak berharap banyak, ia hanya ingin malam ini, saat puasanya untuk pertama kali genap sebulan, dia ingin bercerita dengan bangga pada Ayah-Bunda. Tidak berharap hadiah seperti yang lain. Rinai hanya ingin bercerita. Setelah itu mereka pun boleh pergi lagi." (Liye, 2009: 6)

Pada kutipan pertama Tere Liye menggambarkan perasaan seorang gadis kecil yang bernama Rinai yang sangat merindukan sosok Ayah-Bundanya. Rinai berharap Ayah dan Bundanya hadir pada malam itu karena ia ingin menceritakan kepada mereka bahwa ia bangga sudah berhasil menjalankan puasa selama sebulan penuh. Selain itu, dari kutipan di atas tersirat juga bagaimana pikiran Rinai yang seolah-olah Tuhan tidak adil memberikan cobaan kepada dirinya. Hal ini terlihat pada saat ia menanyakan keberadaan Ayah-Bundanya, sedangkan teman-temannya bisa bersama kedua orang tua mereka. .

Teknik arus kesadaran menurut Abrams (dalam Nurgiyantoro, 2013: 206) adalah teknik narasi yang berusaha menangkap pandangan aliran proses mental tokoh dimana tanggapan indera bercampur dengan kesadaran dan ketaksadaran pikiran, perasaan, ingatan, harapan, dan asosiasi-asosiasi acak. 
"Ya, Koh Cheu-lah yang membangun Pusat Perbelanjaan di atas puing-puing rumah orang tuamu, di atas tumpukan tulang-belulang orang tuamu. Dia selalu dihalang-halangi mendapatkan lahan itu, maka malam itu, saat malam karnaval hari raya, dia menyuruh Plee membakarnya. Tanpa ampun. Selepas kebakaran, Pusat Perbelanjaan itu lantas dibangun atas nama perusahaan lain. Sehingga tidak ada yang tahu Koh Cheu-lah yang membakarnya." Orang dengan wajah menyenangkan itu tersenyum getir." (Liye, 2009: 376)

Kutipan di atas menunjukkan teknik arus kesadaran yang dialami oleh tokoh Koh Cheu. Teknik kesadaran tersebut terlihat pada saat Koh Cheu menyuruh Plee untuk membakar kompleks perumahan tempat tinggal orang tua Ray. Teknik reaksi tokoh adalah teknik yang dimaksudkan sebagai reaksi tokoh terhadap suatu kejadian, masalah, keadaan yang berupa rangsangan dari luar tokoh yang bersangkutan.

"Kau tahu, saat kau masih merangkak di bawah ketiak ibu mu, saat kau masih belajar berjalan, aku sudah membakar ratusan rumah untuk membangun imperium bisnisku. Kau tahu, saat kau masih belajar membuka mulut, belajar bicara, aku sudah menancapkan bisnisku dimana-mana. Suka atau tidak, kau butuh pertolongan." Koh Cheu mendesis. Meletakkan tongkatnya ke atas meja." (Liye, 2009: 373)

Kutipan di atas memperlihatkan bagaimana reaksi tokoh Koh Cheu pada saat membakar kompleks perumahan tempat tinggal orang tua Ray. Koh Cheu melakukan itu semu karena ia ingin merealisasikan bisnis Pusat Perbelanjaan miliknya.

Teknik reaksi tokoh lain adalah teknik yang dimaksudkan sebagai reaksi yang diberikan oleh orang lain terhadap tokoh utama, atau tokoh yang dipelajari kediriannya yang berupa pandangan, pendapat, sikap, komentar dan lain-lain (Nurgiyantoro, 2013: 294).

"Sempurna bukan? Melihat keluarga kau yang begitu bahagia, keluarga yang bangkit dari abu-abu sisa pembakaran mereka. Koh Cheu dan istrinya merasa amat bersalah. Apalagi mengingat balasan yang harus mereka terima: kehilangan anak tunggal dan menantu mereka. Menyisakan Vin yang sama seperti kalian berdua. Yatim-piatu. Pagi itu ketika Koh Cheu datang menawarkan bantuan, sungguh dia melakukannya bukan karena Vin. Dia ingin menebus kesalahan masa-lalunya." Orang dengan wajah menyenangkan itu menghela napas panjang. Merubah posisi duduknya sambil menatap bingkai jendela yang melukis rembulan dan gemintang." (Liye, 2009: 378)

Kutipan di atas di gambarkan Tere Liye sebagai reaksi tokoh lain, yaitu reaksi Koh Cheu yang berusaha menebus kesalahan masa lalu mereka dikarenakan sudah membakar kompleks perumahan orang tua Ray. Hal ini mereka lakukan dikarenakan anak dan menantu kesayangan mereka meninggal dan hanya menyisakan cucu mereka satu-satunya atau dengan kata lain, mereka sudah mendapatkan balasan dari apa yang mereka lakukan kepada keluarga Ray. 
Teknik pelukisan latar adalah teknik yang menggambarkan latar dalam cerita yang dapat mengintensifkan kedirian tokoh.

"Malam terang. Langit bersih tak tersaput awan. Bintang tumpah mengukir angkasa, membentuk ribuan formasi. Angin malam membelai rambut. Lembut. Menyenangkan. Menelisik, bernyanyi di sela-sela kuping. Gema takbir memenuhi jalanan.” (Liye, 2009: 1)

Kutipan di atas memperlihatkan bagaimana seorang Tere Liye mengawali episode satu dalam novel Rembulan Tenggelam di Wajahmu dengan memberikan deskripsi latar suasana atau keadaan yang menyenangkan. Di sana terlihat bagaimana perasaan umat muslim yang sedang menggemakan takbir dan menabuh beduk sebagai wujud kemenangan dan itu semua mereka lakukan dengan ekspresi kebahagiaan.

Teknik pelukisan fisik adalah teknik yang digunakan pengarang dalam menggambarkan fisik tokoh yang memiliki kaitan dengan kejiwaannya, atau paling tidak pengarang sengaja mengaitkannya.

"Diar terdiam lagi, menatap Rehan lamat-lamat. Mereka berbeda umur hampir empat tahun. Rehan enam belas, Diar dua belas. Pertumbuhan fisik mereka yang berbeda membuat perbedaan usia itu semakin kontras. Rehan yang tumbuh pesat terlihat seperti pemuda tanggung. Sedangkan Diar yang kurus, berperawakan kecil terlihat lebih muda dari usianya. Ringkih.” (Liye, 2009: 24)

Pada kutipan di atas, Tere Liye menggambarkan perbedaan fisik Rehan dan Diar. Di sana Tere Liye memberikan penjelasan yang sangat terperinci sehingga pembaca seolah-olah mengetahui keadaan fisik kedua tokoh tersebut yaitu Rehan dan Diar. Pada kutipan di atas, Rehan seperti pemuda tanggung, sedangkan Diar kurus dan berperawakan kecil sehingga terlihat lebih muda dari usianya.

B. Gaya Bahasa

Karya sastra novel tidak bisa lepas dari bahasa. Untuk itu gaya bahasa dalam novel menunjukkan kemampuan penulisnya dalam menguasai kosa kata. Gaya bahasa sendiri merupakan penggunaan bahasa yang khas dari seorang pengarang dalam mengungkapkan pikirannya. Karena gaya bahasa merupakan penggunaan bahasa yang khas tentunya memiliki tujuan yaitu untuk menimbulkan efek keindahan dan daya tarik tersendiri. Begitu juga dengan novel Rembulan Tenggelam di Wajahmu karya Tere Liye yang dikemas sedemikian rupa dengan pemilihan bahasa yang indah dan dipahami oleh pembaca.

Penggunaan gaya bahasa ini bertujuan membantu pembaca agar tidak mengalami kesulitan yang berarti dalam memahami gagasan-gagasan Tere Liye yang dituangkan dalam novel Rembulan Tenggelam di Wajahmu. Selain itu penulis mempertahankan gaya penulisan yang mengandung makna-makna kiasan dalam penulisannya. Hal ini tentunya penulis ingin membangun karakter yang lebih kuat dalam penggambaran tokoh ataupun peristiwa-peristiwa dalam novel. novel Rembulan Tenggelam di Wajahmu karya Tere Liye ini merupakan pola pikir yang luar biasa, dengan bentuk cerita yang unik, serta makna yang disampaikan memberikan kesan yang bermanfaat dan positif bagi pembaca. 
Personifikasi (penginsanan) merupakan suatu corak khusus dari metafora, yang mengiaskan benda-benda mati bertindak, berbuat, berbicara seperti manusia (Keraf, 2009: 140). Berikut kutipan kalimat bergaya bahasa personifikasi dalam novel Rembulan Tenggelam Di Wajahmu karya Tere Liye:

"Malam terang. Langit bersih tak tersaput awan. Bintang tumpah mengukir angkasa, membentuk ribuan formasi. Angin malam membelai rambut. Lembut. Menyenangkan. Menelisik, bernyanyi di sela-sela kuping. Gema takbir memenuhi jalanan."(Liye, 2009: 1)

Pada kutipan di atas, Tere Liye menggambarkan latar tempat dan suasana, yaitu pada malam hari dengan latar suasana yang sangat meriah dimana pada kutipan itu menunjukkan perasaan orang-orang muslim yang bergembira menyambut hari kemenangan atau hari raya. Selain itu pada kutipan di atas Tere Liye juga menuliskan "angin malam membelai rambut" yang mana angin itu digambarkan seolah-olah berwujud manusia yang seakan-akan benar-benar dapat membelai rambut seseorang.

Majas asosiasi sering juga disebut dengan majas perumpamaan yang tergolong ke dalam majas perbandingan. Pembeda antara majas asosiasi dengan majas perbandingan lainnya adalah dalam majas asosiasi membandingkan tujuan atau ide atau gagasan dengan mengumpamakannya dengan kata lain dalam satu kalimat. Dalam novel Rembulan Tenggelam di Wajahmu Karya Tere Liye gaya bahasa asosiasi atau perumpamaan yang penulis temukan terdapat pada kutipan berikut:

\section{Kutipan 1:}

“Angin semilir yang lembut justru menikam perasaan.”(Liye, 2009: 5)

\section{Kutipan 2:}

"Ray bagai bebek tesuruk-suruk ikut." (Liye, 2009: 245)

Pada kutipan (1) Tere Liye menggunakan perumpamaan "angin" sebagai manusia yang seolah-olah dapat menggambarkan perasaan seseorang yang sedang kesepian. Sedangkan "bebek" pada kutipan (2) menggambarkan seseorang yang sedang melakukan aktivitas yang hampir sama dengan cara bebek berjalan. Atau dapat dikatakan juga orang yang mengikuti perjalanan orang lain secara diam-diam agar tidak diketahui.

Sarkasme merupakan suatu acuan yang lebih kasar dari ironi dan sinisme. Ia adalah suatu acuan yang mengandung kepahitan dan celaan yang getir. Sarkasme dapat saja bersifat ironis, dapat juga tidak, tetapi yang jelas adalah bahwa gaya ini akan selalu menyakiti hati dan kurang enak di dengar. Kata sarkasme diturunkan dari kata Yunani sarkasmos, yang lebih jauh diturunkan dari kata kerja sasien yang berarti "merobek-robek seperti anjing", "menggigit bibir karena marah", atau "berbicara dengan kepahitan” (Keraf, 2009: 143).

Meskipun Tere Liye menggunakan gaya bahasa sarkasme dalam novel Rembulan Tenggelam di Wajahmu, akan tetapi hal tersebut tidak menunjukkan karakter tokoh yang jahat dalam novel. hal ini karena Tere Liye menggunakan gaya bahasa sarkasme sesuai dengan waktu dan tempatnya. Berikut kutipan bergaya bahasa sarkasme dalam novel Rembulan Tenggelam di Wajahmu karya Tere Liye:

"Diam. Rehan memutuskan membisu, meski hatinya mengucap sumpahserapah. Penjaga Panti semakin jengkel. Mengangkat bilah rotannya tinggi-tinggi, 
matanya membesar, "Kau sembunyikan di mana semua bungkusan? Ayo jawab... Jawab anak bangsat!!”(Liye, 2009: 11)

Pada kutipan di atas menunjukkan penggunaan gaya bahasa sarkasme. Dalam kutipan tersebut digambarkan bagaimana sikap Rehan yang memilih untuk diam ketika dimarahi oleh Penjaga Panti. Makna dari kutipan di atas yaitu Penjaga Panti yang menyindir Rehan karena ia tidak ingin memberi tahu dimana ia menyembunyikan bungkusan dari para dermawan. Selain itu, Penjaga Panti juga menyindir Rehan karena menurutnya Rehan itu merupakan anak bangsat yang tidak tahu cara membalas budi.

Hiperbola adalah gaya bahasa yang mengandung suatu pernyataan yang berlebihan, dengan membesar-besarkan suatu hal (Keraf, 2009: 135). Gaya bahasa ini digunakan pengarang dalam novel Rembulan Tenggelam di Wajahmu sebagai salah satu cara untuk menggambarkan atau melukiskan kejadian-kejadian yang terjadi dengan pemaparan yang berlebih-lebihan. Berikut ini kutipan-kutipan gaya bahasa hiperbola yang penulis temukan dalam novel Rembulan Tenggelam di Wajahmu:

"Dan sempurna saat bulir pertama air mata Rinai jatuh, seketika petir menyambar terang menyilaukan. Disusul guntur menggelegar mengadukaduk perasaan. Sempurna ketika air mata itu meresap di atas tanahMu, langit entah dari mana datangnya sontak terkepung oleh awan-awan hitam-pekat. Bagai ada yang amat jahil menuangkan tinta hitam ke dalam beningnya kolam. Gelap-Gulita.”(Liye, 2009: 6)

Pada kutipan di atas, sebenarnya digunakan Tere Liye untuk menggambarkan kondisi dan perasaan Rinai yang sangat merindukan kehadiran kedua orang tuanya dengan diibaratkan "seketika petir menyambar terang menyilaukan. Disusul guntur menggelegar mengaduk-aduk perasaan. Sempurna ketika air mata itu meresap di atas tanahMu, langit entah dari mana datangnya sontak terkepung oleh awan-awan hitampekat. Bagai ada yang amat jahil menuangkan tinta hitam ke dalam beningnya kolam" ini merupakan penggambaran perasaan Rinai yang teramat rindu pada orang yang dicintainya. Pada kutipan di atas, Rinai tidak mempunyai banyak keinginan melainkan ia hanya ingin bercerita dengan bangga kepada kedua orang tuanya bahwasanya pada malam itu adalah malam pertama puasanya genap satu bulan.

Berikut kutipan kalimat bergaya bahasa simile dalam novel Rembulan Tenggelam di Wajahmu karya Tere Liye:

"Sebuah mobil patroli petugas lalu-lintas berhasil merapat. Sirenenya mengaum bak teriakan harimau. Empat polisi berloncatan sambil menyambar pentungan di pinggang. Merangsek masuk ke dalam bus. Sudah usai. Kelima tukang pukul itu sudah rebah di lantai bus. Terkapar justru oleh senjata kebanggaan mereka selama ini. Sementara Ray berdiri gemetar di lorong. Gitarnya patah dua tergeletak di bawah salah satu kursi. Kapak itu masih tergenggam di tangannya. Lima belas detik setelah semuanya usai, kesadaran itu baru datang. Naluri aneh jahat itu melesat pergi digantikan oleh kesadaran, ketakutan." (Liye, 2009: 123) 
Pada kutipan di atas, Tere Liye membandingkan antara bunyi sirene mobil patroli dengan suara harimau. Pembandingan tersebut dilakukan semata-mata karena ingin memberikan gambaran kepada pembaca bahwasanya sirene itu berbunyi seperti suara harimau yang sedang mengaum.

C. Latar atau Setting

Segala kejadian dalam kehidupan manusia tidak akan lepas dari ruang dan waktu. Kejadian-kejadian kehidupan manusia dapat direkam dalam sebuah karya sastra. Sebuah karya sastra, terutama prosa, senantiasa menggunakan latar untuk menjalin setiap laku kehidupan tokoh dalam cerita. Latar atau setting dalam novel digunakan pengarang tidak hanya untuk menunjukkan tempat, waktu, dan suasana, tetapi juga menunjukkan nilai-nilai yang ingin disampaikan pengarang dalam novel tersebut.

Tere Liye dalam novel Rembulan Tenggelam di Wajahmu menggunakan latar untuk berbagai kepentingan, seperti penguatan karakter tokoh; menunjukkan tempat, waktu, dan kehidupan sosial tokohnya; menyampaikan nilai-nilai kehidupan; dan lain sebagainya. Berikut ini gaya bercerita Tere Liye menyangkut latar.

"Saat suster itu melambaikan tangan ke arah taksi biru yang dua-tiga berderet rapi di lobi rumah sakit. Saat ketiga dokter itu kembali tertawa-tawa berbincang sambil bermain kartu di ruang jaga yang mewah. Saat hujan masih buncah membasuh kota kami." (Liye, 2009: 18)

Kutipan di atas menunjukkan latar tempat yang sedang berlangsung di Rumah Sakit. Hal ini terlihat karena pada kutipan tersebut dijelaskan ada beberapa suster dan dokter yang sedang berbincang sambil bermain di ruang jaga yang mewah. Selain itu juga dijelaskan ada beberapa taksi yang berderet di lobi Rumah Sakit.

"Pukul 21.00, sedan tua itu sudah melesat di jalanan Ibukota. Menuju pemberhentian pertama. Stadion besar. Malam itu stadion ramai. Ramai oleh orang-orang berlalu-lalang. Malam itu seluruh Ibukota memang ramai. Ramai oleh suara beduk ditabuh bertalu-talu. Ramai oleh suara takbir yang menggema ke segenap penjuru. Karena malam itu karnaval hari raya. Malam kemenangan." (Liye, 2009: 177)

Kutipan di atas menunjukkan latar waktu yang terjadi pada malam hari yaitu pada pukul 21.00. Selain itu juga dijelaskan secara berulang-ulang pada kutipan tersebut yang menyatakan bahwasanya peristiwa itu memang terjadi pada malam hari. Hal ini terlihat pada kalimat "Malam itu stadion ramai", "Malam itu seluruh Ibukota memang ramai". Oleh karena itu dapat disimpulkan bahwa peristiwa itu terjadi pada malam hari.

"Dan sempurna pada saat bulir pertama air mata Rinai jatuh, seketika petir menyambar terang menyilaukan. Disusul Guntur menggelegar menyusul perasaan. Sempurna ketika air mata itu meresap di atas tanah-Mu, langit entah dari mana datangnya sontak terkepung oleh awan hitam pekat. Bagai ada yang 
amat jahil menuangkan tinta hitam ke dalam beningnya kolam.” (Liye, 2009: 6)

Kutipan tersebut menunjukkan latar suasana gelap gulita. Pada kutipan itu, Tere Liye memberikan penjelasan secara rinci bagaimana perasaan Rinai yang dibandingkan dengan kalimat "Disusul Guntur menggelegar menyusul perasaan. Sempurna ketika air mata itu meresap di atas tanah-Mu, langit entah dari mana datangnya sontak terkepung oleh awan hitam pekat. Bagai ada yang amat jahil menuangkan tinta hitam ke dalam beningnya kolam" yang seakan-akan dapat memberikan gambaran kepada pembaca bahwasanya Rinai itu sedang mengalami kesedihan.

\section{PENUTUP}

Berdasarkan hasil penelitian Gaya Bercerita Dalam Novel Rembulan Tenggelam Di Wajahmu Karya Tere Liye Gaya bahasa yang ditemukan oleh penulis dalam penelitian ini yaitu gaya bahasa personifikasi, asosiasi atau perumpamaan, sarkasme, hiperbola, dan simile. Tidak hanya itu, penelitian ini juga menganalisis sampai pada perwatakan tokoh, karena gaya bahasa tertentu juga menjadi ciri tokoh juga. Teknik pelukisan tokoh tersebut adalah teknik dramatik yang meliputi teknik cakapan, tingkah laku, pikiran dan perasaan, arus kesadaran, reaksi tokoh, reaksi tokoh lain, pelukisan latar dan pelukisan fisik. Dalam novel Rembulan Tenggelam di Wajahmu karya Tere Liye, penulis juga menemukan beberapa latar atau setting yang terdapat di dalamnya, yaitu; (1) latar tempat di Rumah Singgah, Toilet Terminal, Gerbong Makan, Rumah Fitri, Pinggir Pantai, Bandara Kota, Rumah Sakit, (2) latar waktu yaitu pada malam hari, dan sore hari, (3) latar suasana yaitu suasana sepi, suasana gelap gulita, suasana ramai, suasana ketakutan, suasana gembira.

Penelitian tentang gaya bercerita Tere Liye dalam novel Rembulan Tenggelam Di Wajahmu masih jauh dikatakan mendalam. Artinya, masih banyak persoalan-persoalan yang luput dari pengamatan dan perhatian peneliti, oleh karena itu diharapkan dengan isyarat ini menarik minat peneliti lainnya untuk melakukan penelitian lebih mendalam dan lebih spesifik mengenai gaya bercerita Tere liye dalam novel Rembulan Tenggelam Di Wajahmu.

\section{DAFTAR RUJUKAN}

Endraswara, Suwardi. 2003. Metodologi Penelitian Sastra. Yogyakarta: Pustaka Widyatma.

Keraf, Gorys. 2009. Diksi dan Gaya Bahasa. Jakarta: PT Gramedia Pustaka Utama.

Liye, Tere. 2009. Rembulan Tenggelam Di Wajahmu. Jakarta: Republika.

Nurgiyantoro, Burhan. 2013. Teori Pengkajian Fiksi. Yogyakarta: Gajah Mada University Pers.

Ratna, Nyoman Kutha. 2008. Stilistika Kajian Puitika Bahasa, Sastra, dan Budaya. Yogyakarta: Pustaka Pelajar.

Sayuti,Suminto A. 2000. Berkenalan Dengan Prosa Fiksi. Yogyakarta: Gama Media. 